\title{
Sustainability for Growth and Productivity of Arabica Coffee in Lowland Regions of Bengkulu Province
}

\author{
Alnopri and Bandi Hermawan \\ Department of Agricultural Cultivation, Bengkulu University, WR. Supratman Street, Bengkulu, 38178, Indonesia \\ E-mail:alnopri_bkl@yahoo.co.id
}

\begin{abstract}
Arabica coffee usually grows well at the latitude of more than $\mathbf{7 0 0} \mathbf{~ m}$ above sea level, but in Bengkulu Province, Indonesia the highland regions are mainly located in the conserved areas and prohibited for agricultural cultivation. These subsequent studies aimed to result in the most adaptive genotype of arabica coffee to the lowland environtment and the best planting gap of shading trees for improved coffee productivity. Two types of technology included in these studies were grafting of arabica and robusta as entress and understump, respectively, and enviromental engineering at a lowland area by planting shading trees at different distances. Four arabica entresses of S-1934, Kartika, Sigararutang and Andung Sari varieties were grafted with robusta understumps to produce so called four "robbika" genotypes. The robbika stumps were grown in the lowland region under shading trees of legume species which were pre-planted with varous planting distances. Results showed that four genotypes of robbika coffee grew better in the lowland region compared to all genotypes of arabica coffee as shown by parameters of growth, physiological characters and yield potential. Environmental engineering treatments showed that the $2.5 \times 2.0 \mathrm{~m}$ planting distance resulted in the best soil and microclimate conditions in the robbika plantation areas.
\end{abstract}

Keywords - Arabica coffee; grafting; sustainable growth and productivity; lowland regions; shading trees.

\section{INTRODUCTION}

The policy on coffee development in Indonesia is directed the increase proportion of arabica coffee production. The policy is taken due to the fact that Indonesia is the main production of robusta coffee. In 2006, arabica coffee only covered the area of 177.10 ha with the productivity of 792 ha $\mathrm{yr}^{-1} \mathrm{ha}^{-1}$. In 2025, it is espected that the arabica area would be 236.00 ha with the productivity of $1,200 \mathrm{~kg} \mathrm{yr}^{-1} \mathrm{ha}^{-1}[1]$.

The environment of arabica habitat is the high country land, temperature between $18^{\circ} \mathrm{C}$ and $25^{\circ} \mathrm{C}$ and rain total between 1,200 and $2,000 \mathrm{~mm} \mathrm{yr}^{-1}$ with 1 to 3 dry months. Favourable soil for arabica is fertile having a thick topsoil, loose and $\mathrm{pH}$ between 5.5 and 6.5 [2]. Arabica coffee usually grows well at the latitude of 700 to $1,700 \mathrm{~m}$ above sea level, optimum at 800 to $1,200 \mathrm{~m}$ above sea level [3], but in Bengkulu Province, Indonesia the highland regions are mainly located in the conserved areas and prohibited for agricultural cultivation.

The Province of Bengkulu the main region of robusta coffee production in Indonesia. Development of arabica coffee in Bengkulu on the highland areas has many obstacles becase most highland sites are located in the conservation forest land. Therefore, the potential of arabica development in Bengkulu must be focused on the cultivation at the lowland. Problems on cultivation practices of arabica coffee at lowland areas arise from low growth rates and yields as well as succeptible to plant disease (Hemileia vastatrix). The answers to these problems are the genetype engineering on arabica coffee spesific for lowland areas and environmental engineering for the arabica habitats.

Genotype engineering is conducted by producing Robbica coffee (i.e., robusta for understump and arabica for entrees) involving grafting technology at soldier phase. The genotype of Robbica coffee will have the superiority of arabica for entrees, including high productionlevel, good quality of seeds and taste. The superiority of robusta for understump is the resistance nemathods and water stress, good rooting systems and already adaptive in robusta center of Bengkulu areas.

Growth environmental engineering can be conducted by growing shading trees therefore the growth conditions are close to the real highland conditions. A research showed that the intensity of shading affected temperature and humidity of air at the coffee nursery [4]. The average daily temperature was 28 to $29{ }^{\circ} \mathrm{C}$ and the humidity was $88 \%$ for the shading intensity of $75 \%$. Therefore, a good management of shading trees may result in suitable conditions of the lowland area for arabica growth. The 
components of growth environment that can be modified are temperatur, humidity, light intensity and soil fertility.

These subsequent studies aimed to result in the most adaptive genotype of arabica coffee to the lowland environtment and the best planting gap of shading trees for improved coffee productivity.

\section{METHODS}

This research was conducted subsequently from 2009 until 2011 [5; 6; 7] the experiment site of Bengkulu City and the laboratory of Bengkulu University. The location of the subsequent study siteswere in the southern part of Sumatera Island, Indonesia as shorwn in Fig. 1. The experiments used a randomized blcok design arranged in a split plot, having four shading intensites as the main plots (planting distances of $2.5 \times 2.0 \mathrm{~m} ; 2.5 \times 1.5 \mathrm{~m} ; 2.5 \times 1.0 \mathrm{~m}$ and $2.5 \times 0.5 \mathrm{~m})$ and ten coffee genotypes as the sub plots (Arabica 1; Robbica 1; Arabica 2; Robbica 2; Arabica 5; Robbica 5). Each combined treatment was subject to three replications, therefore there were 120 plots used in these studies.

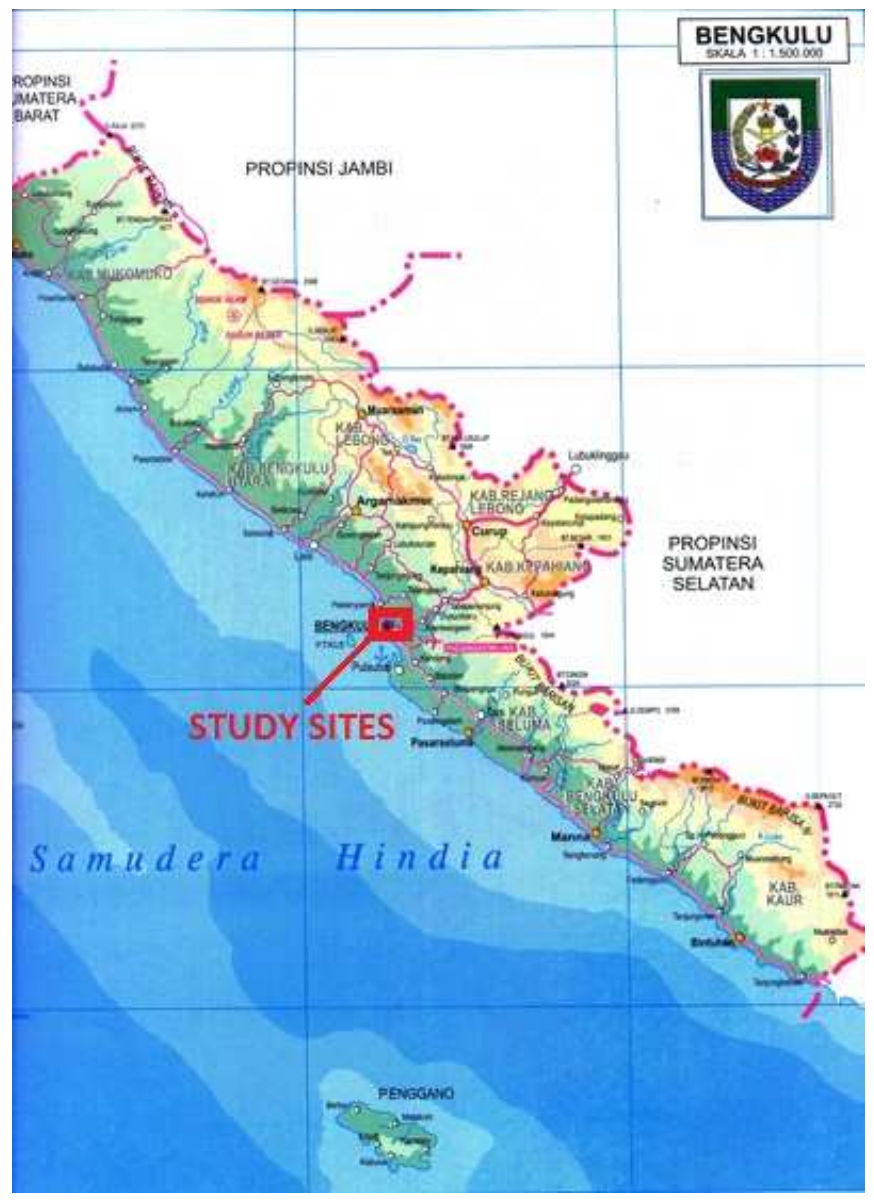

Fig. 1 Location of Studi Sites

Genotype coffee materials used in these studies were the combinations of arabica and arabica as well as of robusta and arabica (called Robbica) as presented in Table 1. These combinations resulted in five genotypes of Arabica and five genotypes of Robbica. Indicators of success were shown by the performances of Robbica and Arabica coffee including growth characteristics (plant height, stump diameters, and leaf numbers), biological characteristics (number of stomate and the degree of leaf colour), biochemestry characteristic as yied predictor (nitrate reductase activiy), and the resistance to H. Vastatrix attack. Growth environmetal conditions such as air tempereture, humidity and soil fertility were also observed.

TABLE I

GENOTYPE MATERIALS OF ARABICA COFFEE

\begin{tabular}{|l|l|l|l|}
\hline No & Genotype & \multicolumn{1}{|c|}{ Under stump } & \multicolumn{1}{c|}{ Entrees } \\
\hline 1 & Arabika-1 & USDA-230762 & USDA-230762 \\
\hline 2 & Robbika-1 & ROBUSTA & USDA-230762 \\
\hline 3 & Arabika-2 & S-1934 & S-1934 \\
\hline 4 & Robbika-2 & ROBUSTA & S-1934 \\
\hline 5 & Arabika-3 & KARTIKA-1 & KARTIKA-1 \\
\hline 6 & Robbika-3 & ROBUSTA & KARTIKA-1 \\
\hline 7 & Arabika-4 & SIGARARUTANG & SIGARARUTANG \\
\hline 8 & Robbika-4 & ROBUSTA & SIGARARUTANG \\
\hline 9 & Arabika-5 & ANDUNGSARI & ANDUNGSARI \\
\hline 10 & Robbika-5 & ANDUNGSARI & ANDUNGSARI \\
\hline
\end{tabular}

\section{RESULTS AND DISCUSSION}

\section{A. Growth Patters of Arabica}

Based on a research parameter of plant height, the studies showed that Genotypes 3 and 4 had the best growth rate when compared to other eight genotypes used in the studies. The current result was consistent with genotype material characteristics of S-1934 variety as an entrees. The variety of S-1934 had the growth types of herb, the canopy of growing vertically and horizontally, and the stump diameter increased rapidly [7].

The performance of Genotype 4, i.e., robusta understump combined with S-1934 arabica entrees, had the highest growth patterns as shown by higher stump diameter. This indicated that the engineering approach by using grafting technology used in these three-years studies had some advantages by combining the superiority of both arabica and robusta.

The highest number of leaf was resulted from Genotypes 6 and 8. Genotype 6 consisted of robusta understump and arabica Kartika entrees. On the other hand, Genotype 8 consisted of robusta understump and Sigararutang variety entrees. Kartika-1 and Sigararutang varieties were small growing varieties of arabica but good canopy sistem. The small growing varieties of arabica were recommended for coffee cultivation on the midleland area at the latitude of about 300 above sea level [8]. According to the above morphological performance of arabica coffee, the performance of new robbica genotypes was significantly better than the pure arabica, i.e., genotypes of RobustaS.1934, Robusta-Kartika 1, Robusta-Sigararutang and Robusta-Andungsari.

\section{B. Physiology and Biochemestry Characteristics of Arabica}

Growth parameters presented by the averages values of stomate number, the leaf colour index, and reductase nitrate activity (RNA) are presented in Table 2 . The performances of the stomate number, leaf colour index and reductase nitrate activity showed that the even numbers of genotypes were significantly better than the odd genotype numbers. The even numbers of genotypes included all robbica types, 
which were acombination between robusta understump and arabica entrees.

TABLE II

Genotype Materials of ARABica CoFFEE

\begin{tabular}{|l|c|c|c|c|}
\hline No & Genotype & $\begin{array}{c}\text { Number of } \\
\text { Stomatae }\end{array}$ & $\begin{array}{c}\text { Leaf Colour } \\
\text { Index }\end{array}$ & NRA \\
\hline 1 & Arabika-1 & $11.56 \mathrm{a}$ & $58.24 \mathrm{~b}$ & $25.92 \mathrm{bc}$ \\
\hline 2 & Robbika-1 & $12.30 \mathrm{a}$ & $56.56 \mathrm{c}$ & $29.23 \mathrm{abc}$ \\
\hline 3 & Arabika-2 & $11.67 \mathrm{a}$ & $62.60 \mathrm{ab}$ & $27.19 \mathrm{abc}$ \\
\hline 4 & Robbika-2 & $11.27 \mathrm{a}$ & $63.52 \mathrm{a}$ & $28.31 \mathrm{abc}$ \\
\hline 5 & Arabika-3 & $11.55 \mathrm{a}$ & $62.25 \mathrm{ab}$ & $25.61 \mathrm{c}$ \\
\hline 6 & Robbika-3 & $11.13 \mathrm{a}$ & $61.58 \mathrm{ab}$ & $30.32 \mathrm{a}$ \\
\hline 7 & Arabika-4 & $10.77 \mathrm{a}$ & $63.33 \mathrm{a}$ & $25.16 \mathrm{c}$ \\
\hline 8 & Robbika-4 & $10.98 \mathrm{a}$ & $65.86 \mathrm{a}$ & $30.05 \mathrm{ab}$ \\
\hline 9 & Arabika-5 & $12.12 \mathrm{a}$ & $63.63 \mathrm{a}$ & $26.48 \mathrm{abc}$ \\
\hline 10 & Robbika-5 & $11.17 \mathrm{a}$ & $6.16 \mathrm{ab}$ & $29.06 \mathrm{abc}$ \\
\hline
\end{tabular}

All genotypes with even numbers used in these subsequent studies resulted in high estimated potential of nitrat reductase activity. Nitrat reductase activity could be used as a sign of biochemical characters consisted of small protein that influenced by environment factors. Therefore, this parameter was very suitable for the population characteriation and selection indicators [9].

The fact that robbica coffee was superior to pure arabica coffee justified that the grafting technology could improve crop performances. The superiority of robusta as the understump was combined with the supriority of arabica as the entrees. Robusta had more resistent characters to the nemathod attack and water stress, had good rooting systems, and adaptable to coffee production centers in midleland and lowland areas, especially in the triangle coffee center of Bengkulu-Lampung-South Sumatera. On the other hand, arabica as entrees resulted in high potential of production, good quality of seeds, good performance of coffee drink, and good commercial values in the international market.

\section{Resistance to Hemileia vastatrix}

Fungi Hemileia vastatrix was responsible for leaf desease attacks to arabica coffee. The resistance of the plant leafs to $H$. Vastatrix was maintaned by nine dominant genes, which were $\mathrm{SH} 1$ to $\mathrm{SH} 9$ genes. For arabica coffee, there were four genes of resistance, including $\mathrm{SH} 1, \mathrm{SH} 2, \mathrm{SH} 4$, and $\mathrm{SH} 5$ genes [10].

Results from three-year studies on arabicacoffee showed that genotypes of robbica were more resistance to the attack of leaf deseases. The attacks on robbica were classified as weak, while the attack levels on pure arabica were classified as medium and high. Genotypes of Robusta-USDA230762, Robusta-S1934, and Robusta-Sigararutang were more resistent to the leaf desease caused by $H$. Vastatrix as shown from the delay on incubation, low percentage of the attacked plants, and low desease intensity.

The resistance of robbica genotypes to the leaf desease was the functional resistance, meaning that these genotypes would represent glucunase and citanase protein at the same time. The combination of both protein was very useful in order to reduce the hypha and to the fungi attack especially for genotypes resulted from S-1934 entrees [11].

\section{Growth Environmental Engineering for Lowland Areas}

Results of soil fertility analysis at the study sites are presented in Table 4. At the end of experiments, the fertility of soils under shading plants grown at $2.50 \times 2.00$ meter was the most suitable for requirement of arabica growth. Soils under these shading plants resulted in high $\mathrm{pH}$ value, higher C-organic, and finer texture compared to shading plants with narrower distances. These soil parameters were responsible for higher availability of phosporous and other nutrients, as well as the holding capacity of soil water.

TABLE III

ANALYSIS OF SOIL FERTILITY UNDER SHADING PLANTS

\begin{tabular}{|l|l|l|l|l|l|l|}
\hline No & \multicolumn{1}{|c|}{ Analysis } & $\begin{array}{c}\text { Pra- } \\
\text { Study }\end{array}$ & $\begin{array}{c}\text { Final } \\
(\mathbf{A})\end{array}$ & $\begin{array}{c}\text { Final } \\
(\mathbf{B})\end{array}$ & $\begin{array}{c}\text { Finalr } \\
(\mathbf{C})\end{array}$ & $\begin{array}{c}\text { Final } \\
(\mathbf{D})\end{array}$ \\
\hline 1 & pH $\mathrm{H}_{2} \mathrm{O}$ & 6.3 & 6.4 & 6.1 & 6.2 & 6.2 \\
\hline 2 & C-organic (\%) & 2.6 & 1.96 & 1.52 & 1.50 & 2.0 \\
\hline 3 & N-total (\%) & 0.19 & 0.19 & 0.11 & 0.15 & 0.20 \\
\hline 4 & $\begin{array}{l}\mathrm{P}_{2} 0_{5} \text { Bray Kurzt } \\
1\end{array}$ & 0.95 & 8.75 & 4.82 & 5.39 & 10.67 \\
\hline 5 & K-available & 0.16 & 0.46 & 0.37 & 0.48 & 0.85 \\
\hline 6 & CEC & 14.16 & 12.35 & 11.7 & 15.27 & 16.64 \\
\hline 7 & $\begin{array}{l}\text { Textur < Sand } \\
(\%)\end{array}$ & 75.26 & 36.74 & 35.67 & 47.34 & 46.79 \\
\hline 8 & $\begin{array}{l}\text { Textur < Silt } \\
(\%)\end{array}$ & 11.74 & 28.84 & 31.90 & 22.52 & 46.79 \\
\hline 9 & $\begin{array}{l}\text { Textur < Clay } \\
(\%)\end{array}$ & 13.00 & 34.42 & 32.43 & 30.33 & 26.06 \\
\hline 10 & $\begin{array}{l}\text { Particle Density } \\
\left(\mathrm{g} \mathrm{cm}^{-3}\right)\end{array}$ & 2.42 & 2.36 & 2.41 & 2.19 & 2.09 \\
\hline
\end{tabular}

Note: :

A : Planting distance of $2.50 \times 2.00 \mathrm{~m}$

B : Planting distance of $2.50 \times 1.50 \mathrm{~m}$

$\mathrm{C}$ : Planting distance of $2.50 \times 1.00 \mathrm{~m}$

$\mathrm{D}$ : Planting distance of $2.500 .50 \mathrm{~m}$

The $2.50 \times 2.00 \mathrm{~m}$ planting distance of shading plants would have the population of 2,000 plants per hectare. That population was about similar to that in pre-yelding plants in the field. For the post-yielding plants, the population of shading plants could be reduced to about 800 plants [12].

\section{CONCLUSIONS}

The sustainability of arabica plantation in Bengkulu Region should shift from highland to lowland areas. The most suitable genotype to grow in the lowland areas was that resulted by combining robusta understumps and arabica entress. Growth environment at the lowland areas might be modified by growing shading plants at the distance of $2.5 \mathrm{x}$ $2.0 \mathrm{~m}$.

\section{ACKNOWLEDGMENT}

Authors thank to University of Bengkulu for reserach funding, and to our students (Roliston Situmorang, Fika Syerena Sinaga, and Rara Lanjasari) for their help in the field measurements.

\section{REFERENCES}

[1] Dirjen Perkebunan. (2008). Coffee Production in Indonesia is the Fourth Position in the World. [Online]: http://databasedeptan.Go.id/bdsp.web/bdsp2088/kompas.com

[2] H.R. Cambrony, Coffee Growing. The Tropical Agriculturalist. The Macmillan Press LTD London, 1992.

[3] Kutaitimur. (2003). Kopi Plantation Cultivation. [Online]: http://www.kutaitimur.co//BBj/teknologi. 
[4] Alnopri, Prasetyo, B.G. Mucitro and Mukhtasar, Growth Engineering of Arabica Coffee Specially in Lowland Area Based on Peroxide Isoenzyme and Reductase Nitrate Activity, Research Report. University of Bengkulu: 2009.

[5] Alnopri, Prasetyo, B. Hermawan, Hartal and Syaifullah, Study on genotype of Arabica Coffee on Lowland and Midleland Area Based on Morphological Characteristics and Reductase Nitrate Activity, Research Report. University of Bengkulu: 2010.

[6] R. Lanjari, Hartal and Alnopri, Resistance Examinations on Ten Coffee Genotypes Resulted from Grafting of Arabica and Robusta at Lowland on Leaf Desease (Hemileia vastatrix Berk. \& Br), Script. Agricultural Faculty, University of Bengkulu: 2011.

[7] Sobadi, A. Dwiputranto, R. Hulupi and S. Mawardi, "Description of S-1934 Variety", Plantation News, no. 11: 1-5, 1991.

[8] S. Mawardi and R. Hulupi, Cultivation of Small Type Arabica Coffee on Midleland. Center for Coffee and Cocoa Research. Jember: 32 pp, 1992.
[9] A. Komariah, A.Baihaki, R. Setiamihardja and S. Djakasutami, "Relations of Reductase Nitrat Activity, Total $N$ and Other Important Characteristics to Water-Resistance Soybean", Zuriat, vol. 15 (2), pp. 163-168, 2004.

[10] H. Semangun, "Introduction to Plant Deseases", Gadjahmada University Press. Jogjakarta: 754 p, 2006.

[11] A. Budiani, I. Susanti, S. Mawardi, D.A.Santoso and Siswanto, "Expression of B-1.3 Gluconase and Citanase on Arabica Coffee Resistent and Not Resistent to Leaf Desease”, Menara Perkebunan, vol.72 (2), pp. 57-71, 2004.

[12] R. Hulupi, S. Mawardi, S. Wiryadiputra, A. Wibawa, A.M. Nur and Y.D. Julianto, "Cultivation Techniques of Arabica Kartika-1 and Kartika-2”, Center for Coffee and Cocoa Research. Jember: 72 pp, 1995. 